\title{
Emerging Legal Control of Infectious Diseases in Nigeria: A Violation of Human Rights*
}

\author{
Grace Abosede Oladele \\ Faculty of Law, Olabisi Onabanjo University, Ago-Iwoye, Ogun State, Nigeria
}

\begin{abstract}
This paper examines the Control of Infectious Diseases Bill, 2020 of Nigeria. It shows that most of the provisions of the Bill give absolute powers to health personnel and police officers to carry out acts that violate the rights of Nigerians including compulsory vaccination, forceful take over, closure and destruction of properties and illegal powers to amend schedules and suspend parts of the bill by the Minister of health. It considers the rights violated under International and Nigerian laws. It examines the provisions of the Constitution of the Federal Republic of Nigeria violated by the Bill. It concludes that for the Bill to be acceptable and effective in democratic Nigeria, its provisions must be reviewed in line with the Constitution of Nigeria and other human rights laws.
\end{abstract}

Keywords - COVID-19, Human Rights, Infectious Diseases, Vaccination.

DOI: $10.7176 / \mathrm{JLPG} / 100-09$

Publication date:August $31^{\text {st }} 2020$

\section{Introduction}

Infectious diseases have at various times existed and been tackled through various measures to abate its spread and devastating effect. Presently, the infectious disease ravaging many countries of the world is the corona virus disease. It spread to Nigeria in February 2020 through an infected Italian man who travelled from Italy to Nigeria. ${ }^{1}$ The disease has since spread to thirty-four States and the Federal Capital Territory. As at 9 June 2020, there were 13,464 infected persons, 4206 discharged persons and 365 deaths in Nigeria. ${ }^{2}$

Measures have been put in place to control the spread of the disease both at Federal and State levels. The President of the Federal Republic of Nigeria (President Muhammadu Buhari) enacted COVID-19 Regulation 2020, which amongst other things, directed a close down of businesses and offices, banned public and religious gatherings and interstate travels in Lagos State, Ogun State and Federal Capital Territory due to the large number of infected persons in those places. The President derived his powers from section 4 of the Quarantine Act, 2004. ${ }^{3}$ State Governors also gave stay home orders and placed restrictions on public and religious gatherings in their States and a ban on inter-state movement except for those rendering essential services. They derived their powers from section 8 of the Quarantine Act.

The Quarantine Act was originally enacted in 1926 but had not undergone any amendment. It is archaic, hence the need for a new and comprehensive law. In April 2020, the House of Representatives of Nigeria, presented a Bill titled "Control of Infectious Diseases Bill, 2020" to repeal the Quarantine Act and control the spread of infectious diseases in Nigeria. ${ }^{4}$ Presenting the Bill was a step in the right direction, considering the present situation of corona virus pandemic and the fact that Nigeria does not have a comprehensive law for the control of infectious diseases. However, most provisions of the Bill infringe on human rights.

The Bill gives the Director General of the Nigeria Centre for Disease Control and the Minister for Health, ${ }^{5}$ arbitrary powers which violate human rights. It empowers them to order compulsory vaccination of anyone in Nigeria. ${ }^{6}$ It also empowers the Director General and police officers to use necessary force and without a warrant, search, take over and shut down any premises, or business; destroy buildings, seize documents and arrest any person under the guise of preventing or controlling the spread of infectious diseases. ${ }^{7}$ In most cases, appeals can only be made to the Minister and his decision is final. ${ }^{8}$ This is an usurpation of the powers of the judiciary under

\footnotetext{
${ }^{1}$ Nigeria Centre for Disease Control "First Case of Corona Virus Confirmed in Nigeria" Available: https://ncdc.gov.ng/news/227/first-case-ofcorona-virus-disease-confirmed-in-nigeria (15 May 2020).

${ }^{2}$ Nairametrics News, 9 June 2020 “COVID-19 Update in Nigeria” Available: https://nairametrics.com/2020/06/10/covid-19-update-in-nigeria/ (9 June 2020).

${ }^{3}$ Quarantine Act Cap. Q2 Laws of the Federation of Nigeria 2004.

${ }^{4}$ Control of Infectious Diseases Bill, 2020 of Nigeria, Available: https://laws.lawnigeria.com/2020/05/01/control-of-infectious-diseases-bill2020-of-nigeria/ (9 June 2020).

${ }^{5} \mathrm{Ibid}$, Section 80 provides that Director-General in the body of the Bill means the Director-General of the Nigerian Centre for Disease Control and Prevention appointed under the Nigerian Centre for Disease Control and Prevention (Establishment) Act No. 18 of 2018, and includes an officer of the Centre acting on his behalf. Minister means the Minister charged with the responsibility for health.

${ }^{6}$ Ibid, Section 47.

${ }^{7} \mathrm{Ibid}$, Sections 12(2)(b), 16(4), 17(5), 18(3), 54(1), 55(1)(b).

${ }^{8} \mathrm{Ibid}$, Sections 16(6) and (7), 17(7) and (8), section 19(5) and (6), 20(5) and (6).
} 
the Constitution, ${ }^{1}$ especially the Supreme Court which is the final court of law in Nigeria. ${ }^{2}$ The provision violates the right to fair hearing under Section 36 of the Constitution.

The Bill further excludes the Minister and his officers from liability in the event of a legal action. ${ }^{3}$ This is an attempt to deprive an aggrieved person of the right to a remedy for the violation of his rights as stated in Section 46 of the Constitution. These defects clearly show that the Bill is oppressive and will trample on the rights of the citizens.

Therefore, this paper examines the relevant provisions of the Bill and the rights infringed upon under international and Nigerian laws. It recommends an urgent review the Bill and adoption of a human rights based legal framework for controlling the spread of infectious diseases in Nigeria.

\section{Control of Infectious Diseases Bill, 2020 of Nigeria}

On 28 April, 2020, the Speaker of the House of Representatives of Federal Republic of Nigeria, Honourable Femi Gbajabiamila presented a Bill titled "Control of Infectious Diseases Bill, 2020". The Bill seeks to repeal the Quarantine Act and enact the Control of Infectious Diseases Bill, make provisions relating to quarantine and make regulations for preventing the introduction into and spread in Nigeria of dangerous infectious diseases and for other related matters. The Bill has passed through first and second reading and has been scheduled for public hearing. ${ }^{5}$

However, most provisions of the Bill are arbitrary and give unjustifiable powers to the Director General of the Nigerian Centre for Disease Control and Prevention, Minister of Health which are bound to be abused. The Bill severely infringes on the rights guaranteed under the Constitution of the Federal Republic of Nigeria and the African Charter on Human and Peoples' Right (Ratification and Enforcement) Act. It also violates the Universal Declaration on Human Rights, International Convention on Civil and Political Rights and the African Charter on Human and Peoples' Right.

\section{Provisions of the Bill that Infringe on Human Rights under the Laws of Nigeria}

In Nigeria, the main human rights laws are - the Constitution of the Federal Republic of Nigeria ${ }^{6}$ and African Charter on Human and Peoples' Right (Ratification and Enforcement) Act. ${ }^{7}$ The rights in these laws are referred to as fundamental rights. Some provisions of the Control of Infectious Diseases Bill, 2020 violate the rights guaranteed under these laws and these are examined below.

\subsection{Compulsory Medical Examination}

Section 6 of the Bill empowers the Director General of Nigeria Centre for Disease Control to order compulsory medical examination or treatment of any person who is, or is suspected to be, a case or carrier or contact of an infectious disease. Failure to go for such test constitutes an offence. This provision puts unnecessary pressure on citizens to go for medical examination even in cases of mere suspicion and the Bill does not state when suspicion can be raised. For example, under the Communicable Diseases Prevention and Control Act 2003 of the Republic of Estonia, ${ }^{8}$ section 19 provides that suspicion of an infectious disease can be raised if a person exhibits clinical symptoms characteristic of the disease or if a person has been in direct or indirect contact with an infected person or animal. This is however, not stated in the Control of Infectious Diseases Bill of Nigeria. Thus, the Director General may order anyone (even if the person does not exhibit symptoms and had not come in contact with an infected person or place), to undergo treatment based on false suspicion.

Suspicion of being infected should be determined by a laboratory test which will ascertain if the person is truly infected. And if the result shows that the person is not infected, such a person should be allowed to go home rather than being kept in isolation or wrongly treated thereby causing health problems for such a person. Mandatory medical treatment violates the right to dignity of human person under Section 34 of the Constitution of Nigeria and right to health under Article 16 of the African Charter on Human and Peoples' Rights (Ratification and Enforcement) Act.

\footnotetext{
${ }^{1}$ Constitution of the Federal Republic of Nigeria Cap. C30 Laws of the Federation of Nigeria 2004 (as amended), Section 46(2) gives a High Court original jurisdiction to hear and determine matters pursuant to enforcement of fundamental rights.

${ }^{2} \mathrm{Ibid}$, Section 235 provides that no appeal shall lie to any other body or person from any determination of the Supreme Court. Thus, decision of the Supreme Court is final.

${ }^{3}$ note 4, Control of Infectious Diseases Bill, 2020, Section 70.

4 Daily Trust News, 12 April 2020 "Nigeria: On the National Emergency Health Bill" Available: https://allafrica.com/stories/202005120027.html (9 June 2020).

5 Premium Times News, 5 May 2020 "Gbajabiamila Defends Infectious Disease Bill, Promises Public Hearing" Available: https://www.premiumtimesng.com/news/headlines/391489-gbajabiamila-defends-infectious-disease-bill-promises-public-hearing.html (10 June 2020).

${ }^{6}$ note 9 , Constitution of the Federal Republic of Nigeria.

${ }^{7}$ African Charter on Human and Peoples' Right (Ratification and Enforcement) Act, Cap. A9 Laws of the Federation of Nigeria, 2004.

8 Communicable Diseases Prevention and Control Act 2003 of the Republic of Estonia, Available: https://www.riigiteataja.ee/en/eli/ee/522122016003/consolide (11 June 2020).
} 


\subsection{Prohibition of Wake Keep and Burial}

Section 12 of the Bill empowers the Director General to prohibit the conduct of wake-keep and burial of a person who is suspected of having died of an infectious disease. The fact that a person died during the period of infectious disease pandemic does not mean the person died of the infectious disease. The cause of death should be ascertained by the Director General before stopping the wake keep or burial of such a person. Stopping the wake keep or burial of a relative adds to the emotional pain experienced by the relative and friends of the deceased. Also, this provision negates the religious beliefs of people who want to bury their deceased according to religious rites. In Nigeria, burial rites are mostly religious-based and unless it is confirmed that the corpse is infected, preventing wake keep and burial by the family members infringes on the right to thought, conscience and religion under Section 38 of the Constitution and Article 8 of the African Charter on Human and Peoples' Rights (Ratification and Enforcement) Act.

\subsection{Unlawful Detention and Isolation of Persons}

Section 13 of the Bill empowers the Director General to detain and isolate any person in a hospital or other places for a period and under such conditions as the Director General may determine if he suspects that the person is infected with an infectious disease. Thus, a person can be detained and isolated anywhere and for as long as the Director General wishes without an order of a court of law, based on his decision that such a person is infected. The question then is - what if the suspicion later turns out to be false? Section 70 exonerates the Director General of any liability in the course of performing his duty thereby leaving the aggrieved person without a remedy. This infringes on the right to a remedy under section 46 of the Constitution.

Section 13 of the Bill violates the right to liberty under Section 35, right to freedom of movement under Section 41 and dignity of person under Section 34 of the Constitution. Similarly, it violates the right to liberty under Article 6 and freedom of movement under Article 12 of the African Charter on Human and Peoples' Rights (Ratification and Enforcement) Act.

\subsection{Forceful Take Over, Closure and Destruction of Property}

Section 15 of the Bill empowers the Minister for Health to issue a notice to take over a person's property and declare it an isolation centre without the consent of the owner. Also, Section 17 provides that the Director General may order the closure of premises or prohibit the sale or distribution of food or water in the premises based on the opinion that it may likely cause an outbreak or spread of an infectious disease. These provisions are arbitrary. It can become a weapon for dealing with anyone in the country. Any member of the public may be targeted and their properties forcefully taken over and converted into isolation centre or closed down by the Director General. This is an infringement on the right to property under section 44 of the Constitution and Article 14 of the African Charter on Human and Peoples' Rights (Ratification and Enforcement) Act.

Furthermore, Section 24 of the Bill provides that an enforcement officer may obtain an order from a court of law to destroy any building in which a case of infectious disease has occurred, or of any article or thing in the interest of public health. This provision is draconian as fumigation or disinfection of an infected building will sanitize it rather than outright destruction. Destruction of property without the consent of the owner violates the right to property guaranteed under Section 44 of the Constitution and Article 14 of the African Charter on Human and Peoples' Rights (Ratification and Enforcement) Act.

\subsection{Restriction and Prohibition of Meetings and Public Entertainments}

Section 19 of the Bill gives the Director General the power to restrict or prohibit, for not more than fourteen days, any meeting or gathering on the ground that such activity is likely to increase the spread of infectious disease. The fourteen days' restriction is renewable. This means that the Director General may decide to prohibit any meeting, gathering or entertainment based on his opinion that it will lead to the spread of an infectious disease. He may deliberately target groups of people or religious houses he intends to deal with, thereby frustrating their activities. All he needs do is to keep renewing the fourteen days restrictions since there is no limit to the number of times renewal can be made. This violates the right to peaceful assembly and association under Section 40 of the Constitution and Article 10 of the African Charter on Human and Peoples' Rights (Ratification and Enforcement) Act.

An aggrieved person may appeal to the Minister whose decision is final. ${ }^{1}$ Also, even though an appeal is pending, the order made by the Director General takes effect from the date specified by him, unless the Minister otherwise directs. ${ }^{2}$ This provision violates the right to fair hearing under Section 36 of the Constitution and Article 7(1)(a) of the African Charter on Human and Peoples' Rights (Ratification and Enforcement) Act and is an attempt to hinder access to a remedy as provided under Section 46 of the Constitution.

\footnotetext{
${ }^{1}$ note 4, Control of Infectious Diseases Bill, 2020, Section 19(5).
}

${ }^{2}$ Ibid, Section 19(6). 


\subsection{Close Down of Occupation, Trade and Business}

Under Section 20(1)(b) of the Bill, the Director General may direct any person carrying on any occupation, trade or business to stop carrying it on, if he thinks it will likely cause the spread of an infectious disease. ${ }^{1}$ This is an inconsiderate provision. Rather than closing down any occupation, trade or business indefinitely, the Director General or Minister should direct the owners/those in charge to fumigate or disinfect the premises or places where such occupation, trade or business is being carried on. If enacted, this provision will render untold hardship on Nigerian traders. It violates the right to work under Article 15 of the African Charter on Human and Peoples' Rights (Ratification and Enforcement) Act.

Also, section 20(1)(b) of the Bill will be difficult to enforce on all business premises. It can only be enforced on select businesses which will be determined by the Director General. This will be sectional and discriminatory, thereby violating the right to freedom from discrimination under Section 42 of the Constitution and Article 12 of the African Charter on Human and Peoples' Rights (Ratification and Enforcement) Act.

\subsection{Unlawful Inspection and Seizure of Properties}

Sections 20(3), 54, 55 and 56 of the Bill empower the Director General, without warrant and with the use of necessary force, to enter, inspect and search any premises; stop, inspect and search any conveyance; take samples of any substance or matter wherever found; seize any substance or matter wherever found; require any person to destroy any food in his possession; furnish any information within his knowledge; or produce any book, document or other record which may be in his custody or possession for inspection, if he believes it is the cause of, is contributory to or otherwise connected with, the occurrence of the outbreak or suspected outbreak. These provisions give the Director General unfettered powers to search any premises, seize item and forcefully obtain any information or document. This will certainly interfere with the private lives, thereby violating the right to privacy under Section 37 of the Constitution.

Destruction of food and seizure of property or document violates of the right to property under Section 43 of the Constitution and Article 14 of the African Charter on Human and Peoples' Rights (Ratification and Enforcement) Act.

The Bill does not state what constitutes necessary force. Thus, any amount of force may be used by the Director General if he feels it is necessary. Use of force will result in physical assault and harm and this will violate the right to dignity of person under Section 34 of the Constitution and Article 5 of the African Charter on Human and Peoples' Rights (Ratification and Enforcement) Act.

\subsection{Unlawful Demand for Names and Addresses}

Section 58 of the Bill empowers a police and/or health officer authorised by the Director-General, to demand for name and address of anyone or occupier or owner of any premises, including a proof of identity. This provision does not state the purpose for which such demand is made but makes non-compliance an offence punishable with a fine not exceeding fifty thousand naira $(\mathrm{N} 50,000) .{ }^{2}$ It clearly interferes with the private lives of people and violates their right to privacy under Section 37 of the Constitution.

\subsection{Compulsory Vaccination}

Section 30 of the Bill gives the Director General the power to order compulsory vaccination of any person leaving or arriving in Nigeria. This is irrespective of the fact that there is no infectious disease pandemic within the country at the particular time or that countries where people are travelling to do not require such vaccination or the disease the vaccine is to abate does not exist in that country.

In addition, Section 47(1) provides that in an outbreak or a suspected outbreak of any infectious disease in any area in Nigeria, the Director General may by order direct any person or class of persons, to undergo vaccination or other prophylaxis within such period as he specifies in the order. Also, if it appears to him that an outbreak of an infectious disease is imminent, he may order or direct any person or class of persons to undergo vaccination or other prophylaxis within such period as he specifies in the order. ${ }^{3}$ Refusal to undergo vaccination constitutes an offence under section 51, punishable under section 68 of the Bill.

Compulsory vaccination is authoritarian and dictatorial. It is a total violation of the right to health under Article 16 of the African Charter on Human and Peoples' Rights (Ratification and Enforcement) Act and right to human dignity Article 5 of the African Charter on Human and Peoples' Rights (Ratification and Enforcement) Act and under Section 34 of the Constitution. Vaccination should be voluntary. People should be encouraged and sensitized on the need to take vaccines which protect against infectious diseases and not forced into doing so. There have been many vaccines introduced in Nigeria against infectious diseases in the past and none has been made compulsory. The fact that corona virus pandemic is rife should not be an excuse for making vaccination

\footnotetext{
${ }^{1}$ Ibid, Section 20(2)(a)

${ }^{2}$ Ibid, Section 58(3).

${ }^{3}$ Ibid, Section 47(2)
} 
compulsory. Some other countries have enacted laws for the control of infectious diseases which make vaccination voluntary and obligatory. For example, under the Prevention and Control of Infectious Diseases Law 2007 of the Republic of Vietnam, ${ }^{1}$ Article 28 provides that the State shall support and encourage citizens to voluntarily use vaccines and medical bio-products. The law makes it obligatory for people who are at risk of contracting infectious diseases in epidemic zones, ${ }^{2}$ children and pregnant women to undergo vaccination. ${ }^{3}$

Thus, compulsory vaccination should be expunged and replaced with voluntary vaccination and the Director General and Minister of Health must be placed under obligation to ensure that the vaccines are safe for human use and where harm occurs, compensation must be paid appropriately. Also, investigation must be made as to the cause of harm. Such provision exists under the Infectious Disease Control and Prevention Act 2009 of the Republic of Korea. ${ }^{4}$ Article $30(1)$ of the Act provides that a vaccination injury investigation team shall be established under the Korea Centers for Disease Control and Prevention to investigate the causes of disabilities and death resulting from vaccinations and compensation must be granted for injury therefrom and to investigate a third party's intention or negligence. This provision respects human rights and should be infused into the Bill.

Furthermore, in times of pandemic, vaccination should be free. However, Section 53 of the Bill provides that vaccination shall be at a fee and failure to undergo vaccination constitutes an offence. ${ }^{5}$ Many Nigerians are poor and cannot afford daily meals. It is therefore inhuman to mandate them to forcefully undergo vaccination at a fee. Even if vaccination is made voluntary, but at a fee, many Nigerians will not be able to afford it and this may lead to further spread of the disease. In periods of pandemic as it is presently, with the corona virus pandemic, vaccination should be free so that all willing Nigerians can undergo it. This will go a long way in preventing the spread of infectious diseases in the country.

\subsection{Immunity Clause}

Section 70 of the Bill gives the Director General, police officers and other relevant health officers, immunity against liability. This provision violates the right of an aggrieved person to a remedy under Section 46 of the Constitution. This provision should therefore be expunged.

\subsection{Unconstitutional Powers to Amend Schedules and Suspend Parts of the Bill}

Section 75 of the Bill gives the Minister of Health the power to amend the Schedules to the Bill. In addition, Section 52(1) gives the Minister the power to suspend all or any of the provisions of Sections 46 - 53 (compulsory vaccination and prophylaxis) through notification in the Gazette. Furthermore, Section 52(2) gives the Minister the power to restore the provisions suspended and order all persons affected by the suspension to perform within such time as he may specify, all acts that remained to be performed by reason of the suspension. This is an illegal provision. It violates Section 4 of the Constitution which gives the legislative arm of government the sole power to amend any existing law. No legislation can override the provisions of the Constitution by delegating legislative powers to the Minister of Health who is a part of the executive. Section 1(3) of the Constitution provides that any law that is inconsistent with the provisions of the Constitution is null and void to the extent of its inconsistency. Therefore, Sections 75, 52(1) and other provisions of the Control of Infectious Diseases Bill, 2020 that violate human rights are unconstitutional, null and void.

\section{International Human Rights Laws}

At the international level, the provisions of the Control of Infectious Diseases Bill, 2020 violates human rights provisions under the Universal Declaration of Human Rights and International Covenant on Civil and Political Rights. In the African region, the Bill violates provisions of the African Charter on Human and Peoples' Rights. Nigeria had domesticated the exact provisions of the Charter and enacted it as the African Charter on Human and Peoples' Rights (Ratification and Enforcement) Act. The relevant provisions of the Charter had already been considered under the African Charter on Human and Peoples' Rights (Ratification and Enforcement) Act and will not be repeated.

The provisions of the Universal Declaration of Human Rights and International Covenant on Civil and Political Rights contravened by the provisions of the Control of Infectious Diseases Bill, 2020 of Nigeria are highlighted below.

\footnotetext{
Prevention and Control of Infectious Diseases Law 2007 of the Republic of Vietnam, Available: https://www.ilo.org/dyn/natlex/docs/ELECTRONIC/84337/93679/F1954113128/VNM84337.pdf (10 June 2020).

${ }^{2}$ Ibid, Art. 29(1).

${ }^{3}$ Ibid, Art. 29(2)

4 Infectious Disease Control and Prevention Act 2009 of the Republic of Korea, Available: https://elaw.klri.re.kr/eng_mobile/ganadaDetail.do?hseq=37239\&type=abc\&key=INFECTIOUS\%20DISEASE\%20CONTROL\%20AND\%2 OPREVENTION\%20ACT\&param=I (10 June 2020).

${ }^{5}$ It is an offence under Section 51 of the Bill punishable under Section 68 (a) in the case of a first offence, with a fine not exceeding one hundred thousand naira $(\mathrm{N} 100,000)$ or to imprisonment for a term not exceeding 6 months or to both; and (b) in the case of a second or subsequent offence, a fine not exceeding two hundred thousand (N200,000) or to imprisonment for a term not exceeding 12 months or to both.
} 
(a) Right to freedom of thought, conscience and religion is recognized under Article 18 of the Universal Declaration of Human Rights and Article 18 of the International Covenant on Civil and Political Rights.

(b) Right to dignity of human person under Article 5 of the Universal Declaration of Human Rights and Article 7 of International Covenant on Civil and Political Rights.

(c) Right to Liberty under Article 3 of the Universal Declaration of Human Rights and Article 9 of International Covenant on Civil and Political Rights. Article 9 of the Universal Declaration of Human Rights provides that non one shall be subjected to arbitrary arrest and detention. Article 9(5) of the International Covenant on Civil and Political Rights provides that a victim of unlawful arrest or detention shall have an enforceable right to compensation.

(d) Right to Freedom of Movement under Article 13 of the Universal Declaration of Human Rights and Article 12 of International Covenant on Civil and Political Rights.

(e) Right to Freedom of Association under Article 20(1) of the Universal Declaration of Human Rights and Article 22 of International Covenant on Civil and Political Rights.

(f) Right to Privacy under Article 12 of the Universal Declaration of Human Rights and Article 17 of International Covenant on Civil and Political Rights.

(g) Right to property under Article 17(1) of the Universal Declaration of Human Rights. Article 17(2) provides that no one shall be arbitrarily deprived of his property. Thus, seizing of properties and documents by the Director General is a violation of Article 17 of the Declaration.

(h) Right to fair hearing under Article 10 of the Universal Declaration of Human Rights and Article 14(1) of the International Covenant on Civil and Political Rights.

(i) Right to freedom from discrimination under Article 7 of the Universal Declaration of Human Rights and Articles 2 and 26 of the International Covenant on Civil and Political Rights.

(j) Right to seek remedy in a court of law under Article 8 of the Universal Declaration of Human Rights.

\section{Conclusion}

The provisions of the Control of Infectious Diseases Bill, 2020 clearly violate human rights. It gives arbitrary powers to the Minister of Health, Director General, health officers under his authority and police officers, and empowers them to carry out activities that infringe on human rights. The Bill which ought to be a laudable legal response to the control of infectious diseases in Nigeria, in particular, during this present corona virus disease pandemic, has turned out to be a draconian Bill which has raised a lot of agitations among Nigerians. It appears to be a plan to deprive Nigerians of their rights and liberties, under the cloak of controlling infectious diseases. It is therefore expedient that the Bill be reviewed before being passed into law.

\section{Recommendations}

The National Assembly, which is the federal law making body in Nigeria, should be guided by the Constitution of the Federal Republic of Nigeria and respect for human rights. It should not make laws that conflict with fundamental rights provisions under the Constitution.

The provisions of the Bill which infringe on human rights should be amended. The Bill should also be reviewed to limit the powers of the Minister of Health, Director General of Nigeria Centre for Disease Control, health officers under his authority and police officers. All provisions that accords them arbitrary powers should be expunged. Section 70 of the Bill which absolves them of liability in cases of violation of human rights should be expunged. Officers should be accountable for their omissions, negligence and excessive use of power and the Bill should not be an exception.

Sections 30 and 47 and other provisions of the Bill that make vaccination compulsory should be expunged. Vaccination should be voluntary and not imposed. Finally, the whole Bill should be diligently reviewed and replaced with provisions that respect human rights and which can effectively control the spread of infectious diseases in Nigeria.

\section{References}

Daily Trust News, 12 April 2020 "Nigeria: On the National Emergency Health Bill" Available: https://allafrica.com/stories/202005120027.html (9 June 2020).

Nairametrics News, 9 June 2020 "COVID-19 Update in Nigeria" Available: https://nairametrics.com/2020/06/10/covid-19-update-in-nigeria/ (9 June 2020).

Nigeria Centre for Disease Control "First Case of Corona Virus Confirmed in Nigeria" Available: https://ncdc.gov.ng/news/227/first-case-of-corona-virus-disease-confirmed-in-nigeria (5 May 2020).

Premium Times News, 5 May, 2020, “Gbajabiamila Defends Infectious Disease Bill, Promises Public Hearing”, Available: https://www.premiumtimesng.com/news/headlines/391489-gbajabiamila-defends-infectiousdisease-bill-promises-public-hearing.html (11 June 2020). 


\section{National Laws}

Nigeria

African Charter on Human and Peoples' Right (Ratification and Enforcement) Act, Cap. A9 Laws of the Federation of Nigeria 2004.

Constitution of the Federal Republic of Nigeria Cap. C30 Laws of the Federation of Nigeria 2004 (as amended). Laws of Select Countries

Communicable Diseases Prevention and Control Act 2003 of the Republic of Estonia, Available: https://www.riigiteataja.ee/en/eli/ee/522122016003/consolide (11 June 2020).

Infectious Disease Control and Prevention Act 2009 of the Republic of Korea, Available: https://elaw.klri.re.kr/eng_mobile/ganadaDetail.do?hseq=37239\&type=abc\&key=INFECTIOUS\%20DISEASE \%20CONTROL\%20AND\%20PREVENTION\%20ACT\&param=I (10 June 2020).

Prevention and Control of Infectious Diseases Law 2007 of the Republic of Vietnam, Available: https://www.ilo.org/dyn/natlex/docs/ELECTRONIC/84337/93679/F1954113128/VNM84337.pdf (10 June 2020). 